custom of sister marriage in the royal Egyptian and Semitic families, which, as she pointed out, were not regarded as unusual when recorded by native historians, and traced the customs to a more prolonged survival of inheritance in the female line in royal families. Dr. Nadine Ivanitzly's communication on "The System of Kinship among Primitive Races in connection with their Mode of Grouping" dealt with the manner in which economic and social factors act and react on the recognition of linship in a group by determining the size of a group, its relation to other and competing groups, and the relation of the individuals within the group.

In physical anthropology, in addition to the paper by Prof. Keith, to which reference has already been made, Dr. Manson exhibited photographs and skiagraphs of members of a family showing hereditary syndactalism and polydactalism, and Dr. G. W. Hanibleton discussed chest types in man in relation to disease. Prof. Guiffrida-Ruggeri's "Notes on the Neolithic Egyptians and Ethiopians." criticising the theories of Prof. Elliot Smith and others on the physical affinities of the early inhabitants of Egypt, and Prof. Elliot Smith's communication on "The Earliest Human Remains from India," owing to lack of time, were taken as read.

At the close of the proceedings, the section, at the invitation of the Ribchester Museum Committee, visited the Roman camp at Ribchester for the formal opening by Prof. F. J. Haverfield of the recentlv completed Museum of Roman Antiquities. Prof. Haverfield then delivered an address on the purpose of the small castella or forts, found scattered over all the north from Chester to Carlisle and from the vale of York to Tyneside, of which Ribchester is an example, as purely military units controlling the country from strategic points.

\section{THE RELATION OF EDUCATION TO INDUSTRY.I}

$A^{\mathrm{T}}$ the last meeting of the British Association in Manchester, in 1887 , the president, Sir Henry Roscoe, in his opening address, referred to national education with patriotic candour, in the following prophetic sentence:- "The country is beginning to see that if she is to maintain her own commercial and industrial supremacy the education of the people from top to bottom must be carried out on new lines. The question as to how this can be most safely and securely accomplished is one of transcendent national importance, and the statesman who solves this educational problem will earn the gratitude of generations yet to come."

A generation has passed since Sir Henry Roscoe uttered his prophecy, and still our national education is, though improved, far from being carried out on the principles and methods which will ensure our industrial supremacy. In other words, "the statesman" has not yet appeared!

By national education we mean, of course, the education of the whole people, not of a class only. From 1872 until as late as 1889 no attempt was made by Government to provide secondary and technical education in continuation of the elementary stage, and in consequence of this the progress made in scientific knowledge bearing on industry and commerce was withheld from our own people who most needed it, and left to other nations who were better qualified to reap the advantage. The results, it is well known, have been lamentable, for it so happened that it was

1 Abridged from a paper read before the Section of Educational Science of the Briti-h Association at Manchester on September 11, by the Right Hon. Sir William, Mather.

NO. 2402 , VOL. 967 during this very period that the most remarkable discoveries and development in science were revealed to the world, and their practical application demonstrated. During that period, and indeed long before, notably in Faraday's lifetime, England produced some of the most eminent men of science in the world, who opened out to us the immeasurable possibilities of adding to the material wealth and prosperity of our country by the adoption of their discoveries.

Only two countries, however, were ready to take practical advantage of these discoveries owing to their widespread facilities for education ranging through the elementary to secondary and technical schools up to scientific teaching in the universities. These countries were America and Germany.

Consequently the great discoveries relating to the utilisation of those subtle forces of electricity and magnetism achieved their first triumphs in these two countries, where the spirit of education had long before penetrated the lives of the people and prepared them to adopt and apply the new revelations of science to the common needs of human life.

These great movements stirred our Grovernment at last to send out a Royal Commission to investigate the educational facilities in the secondary and technical schools of foreign countries. Oh, the pity of it! That a country which had enjoyed the greatest opportunities for the application of scientific discoveries and methods to industry through the undisturbed monopoiy of engineering, chemical, and other industries extending over a full century, should have neglected the only means of retaining that position by the adoption, during the years of expanding wealth and prosperity, of a system of universal, free, and enlightened education open to every class throughout the land! The reports brought back from Europe by the Royal Commission, and one from America, written by myself after eight months' investigation, spread alarm throughout the United Kingdom and the British Empire. These reports were published in 1884. No action was taken by Parliament until $\mathrm{x} 889$, when happily a Technical Instruction Act was passed, within two days of the close of the session, but almost by a fluke even then, owing to the efforts of a few desperate men on both sides of the House who believed that "through lack of knowledge the people perish."

Probably no Act of Parliament was ever seized upon with such avidity as this Technical Instruction Act, for, as the municipalities themselves were by the $\Lambda$ ct constituted the local administrative authorities, the large manufacturing districts, notably Manchester, Salford, and other parts of Lancashire, were especially eager in pressing for its adoption. The following year the "whisky and beer tax" was earmarked for the support of technical education, which resulted in numerous fine institutions being erected in many parts of the country. In 1902 secondary education was adopted permissively in a new Elementary Education Act, and though not adequate to meet the wants of the country, it was received with thanks for small mercies owing to the fact-which in some other countries would have been foreseen-that no system of thorough technical education can be carried out where secondary education is a missing link, so that for a time our rational system of public elementary and technical education minus the secondary was more like "a rope of sand than a chain of welded links."

As a result of the passing of the Technical Instruction Act of $188 \mathrm{a}$, the development of technical instruction was so rapid that in 1895 an Association of Technical Institutes was formed. A large number of new schools have been erected solely for the purpose of technical instruction, and are equal in equipment and staff to the average of those in the United States and 
on the Continent. Such, for instance, are the schools of Manchester, Salford, Birmingham, Belfast, Sheffield, Bradford, Bristol, Edinburgh, Nottingham, London, and of these several take rank as technical universities where day students may graduate and recognised degrees may be obtained. In particular, the Imperial Collage of Science and Technology and the Manchester School of 'Technology are not surpassed by any similar institution in the world.

There are now eleven universities in England and Wales, including the ancient ones of Oxford, Cambridge, and Durham. The latter have conformed to the spirit of the age by adapting themselves to the requirements of science, while the more modern universities, though primarily established to meet the needs of industrial development, have taken ample care of the equally important subject of the arts.

A general survey of our present equipment for national education would, however, clearly show that we are still far below the standard our industries require if they are to compete successfully with those of other countries; therefore the most reactionary form of economy during the war would be the reduction of Government grants to education of any grade.

It would be noted also that no provision has yet been made to continue the education begun in the elementary schools through the period of adolescence - the impressionable period for good or evil-in the life of our young people who at fourteen years of age must begin to earn something towards their own cost of living. Each year something like 600,000 of these young people leave the elementary schools, forming a population of about two millions of young people, from fourteen to seventeen years of age, a prey to many evil influences, and comparatively few of them are accounted for in the attendances at the evening schools. Special provision for them has not yet been made, nor has any definite system of continuation schools for the manual worker yet been established; consequently the expenditure on public elementary education is largely wasted, and the mental, moral, and physical training of the children of the nation is suddenly arrested at fourteen years of age.

This link in the chain of education is so vitally important from the industrial point of view alone that it should be dealt with without delay by a special committee of industrial and educational experts; for after this war more than ever shall we need to use every advantage that the highest education can confer upon our people in order to utilise the ample material resources of all kinds which we possess, if we wish to maintain our place in the world of industry and commerce.

At this point I will venture to express a doubt as to the efficiency in administration of our national education system at the top, either for initiation or control. A Department of Education, with a Cabinet Minister as president, assisted by a permanent Secretary of Education and a vast number of inspectors and examiners and Civil Service clerks is, in my opinion, unsuitable for our country as well as extremely uneconomical. A bureaucratic spirit creeps into such a Department, without any one person being specially to blame, and such a spirit is the obstacle to $\in \mathrm{n}-$ lightened progress.

The freedom and responsibilities of local administrative authorities, acting through competent directors of education and committees composed largely of the best and most enlightened in the community as coopted members, may be, and in fact are, frequently impaired or destroyed altogether.

The glaring inconsistency of the Board of Education, as at present constituted, lies in the political necessity of changing the president at every change of Government. The education of the people of the nation is a subject too sacred to be rendered liable to the whims and caprices of party politics.

A small salaried Council or Royal Cummission of Education, appointed by Parliament from the best men the country possesses, regardless of party, each retiring at fixed periods, but eligible for reappointment, would suffice to represent the State in all respects, while ensuring the continuity of principles and methods of progressive education. The local authorities, under such conditions, would undertake large responsibilities with greater freedom, and higher educational efficiency would be assured throughout their respective areas of administration.

One's mind naturally associates the clesire for true education chiefly with the industrial classes, and especially so in these times when, under the terrible stress and strain of a vast war, the real qualities of men and things are disclosed. It is obvious that a more thorough and enlightened system of education such as we have been considering would in the course of years render the relations between employer and employed totally free from the troubles we have had and must have from time to time under present conditions.

These disputes arise out of a sense of injury, real or imaginary, on the part of one side or the other, generally in connection with wages and hours of labour, or with questions of discipline and business management. Evidence is accumulating to prove that the relationship between employer and employed has hitherto, generally speaking, been based on false and glaringly unscientific principles. Trades unions and employers' federations exist more for organised defence and resistance than for peaceful progress, and it lies in the very nature of the present system of industrial management that this should be so. There is really as little cause for the two elements involved in industry, namely, capital and labour, to be divided, as for a household to be divided against itself. Employers and employed live, as it were, under one roof and for one purpose, the one being absolutely dependent on the other. 'They must rise, continue, or fall together. For want of a thorough understanding of this economic law, as old as the hills, yet never universally recognised, the path of industrial development has been strewn with the wreckage of lives, the waste of capital and energy, and at times with incalculable misery for thousands of women and children comparable only to a state of active warfare.

Where there is no true vision the people perish. Without the desire to learn, to know, to see and trust to a better way than that of recurring strife, the people deserve to perish. We must have visions in relation to industrial peace such as we visionaries hold in relation to international peace. After this Armageddon has been fought out and the victory won by those who fight for truth, justice, and right, against what appears to be the frantic force of evil doers, we must resolve to start again on a higher plane of industrial relationship, in the attainment of which education on the lines already indicated must necessarily be the leading factor.

No country in this world can so easily change the moral and mental growth of its children from the wrong direction to the right as Great Britain can. We possess absolute political freedom, the poorest of the poor amongst us casting as potent a vote under our self-governing constitution as the richest magnate in the land. With the political freedom and individual responsibility such as we enjoy, perfect discipline must ensue if we become educated scientifically to do the necessary thing in the right way, for the welfare of the country and of all who dwell therein.

If liberty and self-government by the people for the NO. 2402, VOL. 96] 
people do not yield this result, it is obvious that we are not efficiently educated, that is, we are either not intelligent enough to know the right way from the wrong, or, knowing it, we do not care to follow it; which means that our moral nature, or higher self of spirit and conscience, has not become educated equally with our intellectual abilities.

The one outstanding menace, which imperils our very existence as an industrial nation, is the chronic separation of capital and labour, employers and employed, into opposing camps. Until the necessity of perfect unity of interest, of motive, and of purpose is recognised and established, we are building our industrial edifice on the sand, liable at a moment's notice to be shattered by the winds and storms of passionate discontent which sweep away what the best culture and skill may have erected. It is eminently unscientific to build on sand when rock is at hand. In building up our industries scientifically let us not forget that in its broadest sense science, as has been well said, "includes the elements of the theory of morals and those of political and social life." There is a science, therefore, which if applied to the elements of capital and labour will hlend them into one organic, harmonious whole. The science of education will teach both labour and capital to look at the problems of industrial growth and success with cultured minds, instead of as now with minds only half made upprone to err, to misjudge men and things, unable to see with an instructed sense of proportion, to differentiate between that which is true and that which is false, between right and wrong, in the complex questions affecting both. The science of management is as important as the science of mechanics. The latter shows the laws of right construction; the former, the way to peaceful control, to unity of purpose, and, above all, to equity in sharing results of the organic whole of capital and labour.

\section{SMITHSONIAN EXPLORATIONS.}

A

FULLY-ILLUSTRATED pamphlet containing brief accounts of the more important explorations and field-work undertaken during I914 by members of the staff of the Smithsonian Institution proper and of its branches, the National Museum, the Bureau of American Ethnology, and the Astrophysical Observatory, has recently been issued.

Dr. C. D. Walcott briefly outlines his summer's work in British Columbia and Montana, in continuation of his previous geological explorations in those regions. In the lower portion of Deep Creek Canyon, south-east of the city of Helena, a deposit of siliceous shale was examined, where some years ago Dr. Walcott discovered the remains of crab-like animals suggesting in form the fresh-water cray-fishes found in streams and ponds all over the world. "These fossils," says Dr. Walcott, "are the oldest animal remains now known, and the algal deposits, which occur at intervals for several thousand feet below the shales containing the crustaceans, are the oldest authentic vegetable remains. It is also most interesting that two types of bacteria have been found in a fossil state in the rock in association with the algal remains."

Continuing the excavations at the cave deposit near Cumberland, Maryland, Mr. J. W. Gidley, of the U.S. National Museum, has added to the already important collection from this region more than 400 specimens of fossil animals, deposited there in Pleistocene time. Among these was a practically complete skeleton of the large extinct peccary, measuring more than $4 \mathrm{ft}$. in length, a partial skull NO. 2402 , VOL. 967 of a wolverine, and several skulls of extinct species of the black bear.

Mr. H. C. Raven, who has been collecting animals and birds for the Smithsonian Institution through the generosity of $\mathrm{Mr}$. W. L. Abbott, gives interesting information respecting the inhabitants and the animals of Celebes, Malay Archipelago. Mammal life, according to Mr. Raven, is not nearly so plentiful in Celebes as in Borneo, where he was collecting during the previous season, but several peculiar animals have been captured by him, among them a specimen of Babirussa, a pig with peculiar erect tusks curved backward above the forehead.

An expedition under the joint auspices of the Smithsonian Institution and the Cuban Government spent two months on the coast of western Cuba for the purpose of making a complete biological survey of the waters of that region, and incidentally to obtain specimens tor the exhibition series of the National Museum. The Smithsonian was represented by Mr. John B. Henderson, a Regent of the Institution, and Dr. Paul Bartsch, of the National Museum. Extensive dredging operations for securing marine specimens were carried on daily, and from several shore stations large numbers of specimens of Iand forms were taken. The expedition was quite successful, and a great quantity of valuable material is now in the hands of specialists of the National Museum for final report. Particularly good were the collections of marine organisms, especially the molluscs.

Early this year arrangements were made whereby Mr. Neil M. Judd, of the National Museum, was enabled to accept an invitation to participate in the archæological investigations in Guatemala, conducted by the American School of Archæology. Mr. Judd's special work was to superintend the making of plaster casts of several of the huge stone monuments that have made world-famous the ruins of the socalled "Temple Court," the religious centre of the sacred city of Quirigua. After this work, Mr. Judd paid a brief visit to the Mexican border to ascertain the anthropological possibilities among the Indian tribes of this region. But little survives, in the remnants of the Quiche, Cachiquel, and Tzutuhil tribes, to indicate the strength and magnificence of the Quiche empire which Pedro de Alvarado destroyed in $1^{2} 3$, at the beginning of his conquest of Guatemala. Although the natives of these interior valleys have always been considered treacherous, Mr. Judd experienced few difficulties, and his hurried journey seems to indicate that extended anthropological investigations in this region will be as easy as they are desirable.

\section{UNIVERSITY AND EDUCATIONAL INTELLIGENCE.}

Cambridge.-Sir W. H. Solomon and Prof. G. H. Bryan have been elected to honorary fellowships at Peterhouse.

Leeds.-The Senate, at a meeting held on November 3 , passed a resolution expressing deep regret at the death of Sir Arthur Rücker. The Senate places on record its sense of obligation to Sir Arthur Rücker, who, with his colleagues forming the first staff of the Yorkshire College of Science, laid the foundations of its intellectual work and corporate life. It was their advice which encouraged the council of the Yorkshire College of Science so to widen the scope of its studies as to enable it to develop into a University embracing the disciplines of arts, science, medicine, and technology. Furthermore, the Senate records its grateful appreciation of the part which, in his last 